\title{
"Quando um justo governa, o povo se alegra": modus operandi evangélico nas eleições à Assembleia Legislativa do Paraná, em 2018
}

\author{
Frank Antonio Mezzomo* \\ Brandon Lopes dos Anjos** \\ Cristina Satiê de Oliveira Pátaro***
}

\section{Resumo}

Este artigo objetiva analisar as estratégias de campanhas de seis políticos evangélicos que receberam apoio oficial de suas denominações durante a campanha eleitoral à Assembleia Legislativa do Paraná, em 2018. Buscamos compreender como esses acionam elementos da religião procurando divulgar e justificar seus discursos e pautas cristãs. Por meio de identificação e coleta de materiais de campanha, publicados em fanpages dos candidatos, construímos três eixos de investigação, a fim de problematizar as formas como a religião é invocada nas campanhas. Percebemos a recorrência a elementos religiosos nas postagens, marcadas com um teor bélico, que sinalizam para um modus operandi evangélico de atuar em eleições no Brasil, em que as dimensões da religião e da política não parecem se incomodar com suas proximidades.

Palavras-chave: Religião e Política; Evangélicos; Batalha espiritual; Apoio oficial das denominações; Assembleia Legislativa do Paraná.

\section{"When The Righteous Thrive, The People Rejoice": Evangelical Modus Operandi In The 2018 Elections To The Legislative Assembly Of Paraná}

\footnotetext{
Abstract

This article intends to analyze the campaign strategies of six evangelical politicians who received official support from their denominations during the electoral campaign to

* Universidade Estadual do Paraná. Doutor em História Cultural. Professor do Programa de Pós-Graduação Interdisciplinar Sociedade e Desenvolvimento e do Programa História Pública da Universidade Estadual do Paraná.

** Universidade Estadual do Paraná. Bolsista CNPq.

*** Universidade Estadual do Paraná. Doutora e Educação. Professora do Programa Interdisciplinar Sociedade e Desenvolvimento e em História Pública da Universidade Estadual do Paraná.
} 
the Legislative Assembly of Paraná in 2018. We seek to understand how they employ religious elements by seeking to disseminate and justify their speeches and Christian agendas. Through the identification and collection of campaign materials, which were published on the candidates' fanpages, we constructed three research axes in order to problematize the ways in which religion is invoked in the campaigns. We perceive the recurrence of religious elements in the posts, marked with a warlike tone, point to an evangelical modus operandi of taking part in elections in Brazil, where the dimensions of religion and politics do not seem to bother with their proximity.

Keywords: Religion and Politics; Evangelicals; Spiritual battle; Official denominations support; Legislative Assembly of Paraná.

\section{"Cuando um hombre justo gobierna, la gente se regocija": modus operandi evangelic en elecciones a la Asamblea Legislativa de Paraná, 2018}

\section{Resumen}

Este artículo tiene como objetivo analizar las estrategias de campaña de seis políticos evangélicos que recibieron el apoyo oficial de sus denominaciones durante la campaña electoral a la Asamblea Legislativa de Paraná en 2018. Buscamos entender cómo desencadenan elementos de la religión al tratar de difundir y justificar sus discursos y agendas cristianas. Mediante la identificación y recopilación de materiales de campaña, publicados en fanpages de candidatos, construimos tres ejes de investigación para problematizar las formas en que se invoca la religión en las campañas. Notamos la recurrencia de elementos religiosos en las publicaciones, marcadas con un contenido bélico, que indican un modus operandi evangélico de actuar en elecciones en Brasil, donde las dimensiones de religión y política no parecen molestar con su entorno.

Palabras clave: Religión y política; Evangélicos; Batalla espiritual; Apoyo oficial de denominaciones; Asamblea Legislativa de Paraná.

\section{"Como ouvirão, se não há quem pregue?": uma introdução}

"A palavra do Senhor diz que quando um justo governa, o povo se alegra, mas quando o ímpio governa, o povo geme [...] mas o Brasil é do Senhor Jesus, o Brasil não é de Satanás, o Brasil não é do Diabo”, declarou o Pastor Luciano Baruk, durante um vídeo em que falava de sua luta na busca por conquistar o cargo de deputado estadual no Paraná em 2018. Além dessa declaração, frases como "a deputada da família”, "hipocrisia é orar pelos filhos e votar em quem defende a ideologia de gênero, o aborto e a liberação das drogas", "tenho representado e defendido os valores cristãos", "sou tradicional, contra a ideologia de gênero", entre outras, demonstram o tom dado por parte dos candidatos evangélicos em suas campanhas, permeadas de elementos religiosos, pautas de cunho moral, bênçãos institucionais, 
entre outras estratégias, em uma "batalha contra o mal" que estaria tomando conta do campo político. Assim, utilizam o sagrado como forma de atrair eleitores e verbalizar suas propostas de teor religioso, apresentando-se como "representantes de Deus" na política.

Diante desse quadro, este artigo busca apresentar e analisar as estratégias utilizadas por candidatos evangélicos durante o período eleitoral de 2018, quando esses agentes buscavam uma cadeira na Assembleia Legislativa do Paraná (ALEP), tendo como lócus de análise a campanha realizada na mídia social Facebook. Com foco naqueles que utilizaram com maior intensidade representações religiosas, apoio institucional e/ou ministerial e, sobretudo, temas e pautas voltadas à moralidade, procuramos identificar os valores e crenças acionados no decorrer do pleito, conforme são empregadas como tática de persuasão e legitimação de suas propostas. Assim, objetivamos contribuir para os estudos relacionados à permeabilização e imbricação das fronteiras entre os campos da religião e da política, a partir das interrelações e representações dos candidatos evangélicos e suas composições na esfera pública.

Por meio de estudos já produzidos sobre a temática (CARVALHO JUNIOR; ORO, 2017; BURITY, 2011; CAMURÇA, 2008; MARIANO, 2005; entre outros) é notória a participação de candidatos que acionam elementos da religião durante a campanha, denominados aqui como religiosos políticos ${ }^{1}$. Devido à participação efetiva desses agentes no âmbito governamental, articulando suas estratégias de forma que suas demandas e seu ethos sejam representados e instituídos na esfera pública, não se pode ignorar a visibilidade das religiões no cenário contemporâneo, quadro que atribui relevância a esta investigação. Em resposta ao apóstolo Paulo, quando questiona sobre quem "pregará" para que a sociedade ouça, os religiosos políticos estão dispostos não só a discursar dentro dos templos, mas a agir de forma enfática no campo político em prol de suas reinvindicações.

\section{"E como pregarão, se não forem enviados?": participação dos evangélicos na política}

Desde o final da década de 1980, os acordos e relações entre o Estado brasileiro, que se autodeclara laico, e a pluralidade de expressões religiosas,

\footnotetext{
Os religiosos políticos, no entendimento de Carvalho Júnior e Oro (2017, p. 19), são caracterizados como "sujeitos detentores de um pertencimento religioso anterior a sua eleição, que se utilizam deste pertencimento como capital político, mesmo que de forma sutil, e que, uma vez eleitos, mantêm o seu vínculo religioso de forma explícita".
} 
por meio da política e da cultura, parecem se opor ao pensamento de Max Weber, quando pondera sobre um "desencantamento do mundo" e, consequentemente, uma "saída da religião" para a esfera privada, em uma transição da heteronomia para a autonomia dos indivíduos. Essa inserção da religiosidade na cena pública, protagonizada pelos evangélicos, principalmente os pentecostais, tem conquistado espaço, seja mediante a publicização da fé por meio das mídias, passeatas e monumentos públicos (GIUMBELLI, 2014), ou por meio da participação política, nos cargos do executivo e legislativo. Essa atuação crescente trouxe ao cenário eleitoral e aos mandatos desses agentes os princípios, valores e manifestações de suas religiosidades. Assim, parece adequado o entendimento de Novaes (2012, p. 184), quando afirma que "a dimensão religiosa tem resistido a se circunscrever à vida privada, ao foro íntimo e hoje ganha outros fôlegos não previstos na grande narrativa que separou religião e política, o público e o privado, magia e religião". Deste modo, esses religiosos políticos agora são comissionados a "pregar" fora dos púlpitos, objetivando serem "enviados" para registrar as demandas do Senhor na sociedade.

No Brasil, mesmo após a promulgação da primeira constituição republicana, em 1891, que adotou a separação dos campos político e clerical, a Igreja Católica continuou a exercer sua posição de influência. Esse quadro passou por um processo gradativo de arrefecimento, com ápice durante o período da ditadura militar no Brasil (1964-1985), quando alguns setores da instituição se converteram "em uma influente força de contestação política ao regime ditatorial e conflitou abertamente com os governos militares em assuntos relacionados aos direitos humanos e promoção da justiça social" (CANCIAN, 2016, p. 96). Além disso, a partir da década de 1970, houve um decréscimo da quantidade católicos no Brasil, que contabilizavam $92 \%$ da população na época, passando para 61\%, em 2014. Paralelo a isso, sucedeu um aumento no número de evangélicos $(26 \%)$ e dos denominados "sem religião" $(8 \%)$, como aponta uma pesquisa realizada pela Pew Research Center em 2014. Mesmo que o catolicismo prossiga sendo a denominação majoritária dentro do cristianismo, não se pode comparar católicos e evangélicos apenas quantitativamente, já que estes últimos costumam apresentar maior envolvimento com suas denominações, sendo indispensável discriminar confessionalidade de militância religiosa (GUADALUPE, 2018).

Concomitante a esses acontecimentos, os evangélicos de vertentes históricas que se instalam no Brasil a partir de meados do século XIX 
aparentavam demonstrar indiferença em relação à política, focalizando suas ações em trabalhos voltados para as áreas da educação e da assistência social. Sua inserção pouco expressiva na esfera pública foi profundamente influenciada por sua visão escatológica, posicionando-se como cidadãos de uma pátria vindoura e que, por isso, deveriam abster-se das "coisas mundanas", dentre elas a política, exercendo sua participação na sociedade por meio de pregações e orações para a "salvação das almas" (GUADALUPE, 2018; CAMPOS, 2013). Tal percepção foi alterada paulatinamente, até a década de 1980, quando a participação desses sujeitos se apresenta de forma mais incisiva (MEZZOMO; PÁTARO, 2017; CARREIRO, 2017), principalmente de evangélicos de vertentes pentecostais e neopentecostais. Esses, ao contrário dos protestantes missionários, trouxeram em seu escopo pautas anticomunistas e antiecumênicas, assim como investiram em estratégias de evangelização massiva. $\mathrm{O}$ aumento de seguidores dessas denominações, aliado ao protagonismo de líderes nacionais, possibilitou a introdução desses agentes na arena política (GUADALUPE, 2018), com o "lançamento de candidaturas de pastores, bispos ou fiéis, apoiados pelas igrejas e fazendo uso explícito de símbolos religiosos em suas campanhas" (SEXUGI; MEZZOMO; PÁTARO, 2018, p. 225). O deslocamento do eixo "missionário-protestanteestrangeiro" para "pastor-evangélico-nacional", bem como a exposição e aceitação de uma posição escatológica neopentecostal, na qual a ênfase se desloca da esperança do reino milenar de Cristo para a ideia de batalha espiritual, Evangelho da Prosperidade ${ }^{2}$ e a centralidade do presente histórico, contribuíram de forma expressiva para a conquista dos evangélicos no espaço público (GUADALUPE, 2018; ROCHA, 2009).

Essa inserção expressiva de candidatos que se identificam como evangélicos acompanha o crescimento do número de adeptos as diversas denominações da vertente religiosa, principalmente pentecostais e neopentecostais. A própria consolidação do termo "evangélico", como aponta Giumbelli (2014), está relacionada ao protagonismo dos pentecostais nas últimas décadas. Antes denominados "crentes", esse grupo se apropriou da titulação, principalmente pelas lideranças que se projetaram na cena pública, tornando a classificação mais ampla, capaz de "abranger clássicos e pentecostais, sem precisar depender de nenhum mecanismo representativo

2 De acordo com Machado e Burity, a "Teologia da Prosperidade promoveu um deslocamento das expectativas milenaristas de salvação para uma vida de graças no presente, favorecendo a inserção dos pentecostais na política” (2014, p. 604). 
para sua sustentação" (GIUMBELLI, 2014, p. 191). Desde a década de 1980, no Brasil, houve um aumento significativo no número de evangélicos, que passaram de 6,6\% em 1980, para 15,4\% em 2000, 22,2\% em 2010, 26\% em 2014 e 29\% em 2016, como também uma queda no número de seguidores do catolicismo (PIERUCCI, 2012), que diminuíram de 73,6\% em 2000, para 64,6\% em 2010, 61\% em 2014 e 50\% em 2016 (DATAFOLHA, 2016; PRC, 2014; IBGE, 2012).

Assim, observamos como os evangélicos se articulam para proliferar suas referências e ocupar posições, em busca de uma maior visibilidade, criando uma "cultura pública" (GIUMBELLI, 2014, p. 194). Tais ações são perceptíveis nas apresentações midiáticas em inaugurações de templos, como no caso do templo de Salomão, pertencente à Igreja Universal do Reino de Deus (MONTERO; SILVA; SALES, 2018), nas inserções de datas simbólicas nos calendários oficiais, como o Dia do Evangélico (MEZZOMO; PÁTARO; PINHEIRO, 2019; BOSISIO, 2018), em diversos meios de comunicação, principalmente em cultos televisivos (BISPO, 2018), em combates às pautas que fogem à moralidade cristã (LUNA, 2018) e, inclusive, em sua integração no campo político, talvez uma das faces mais publicizadas e controversas. Desse cenário, rapidamente sumarizado, podemos afirmar que candidatos evangélicos, muitos dos quais catapultados por suas igrejas, não parecem distantes, afinal construíram suas campanhas recorrendo aos discursos, símbolos e apoios de lideranças religiosas.

\section{"A quem enviarei, e quem há de ir por nós?": os religiosos políticos}

A eleição para os cargos de deputado estadual no Paraná ocorreu no dia 07 de outubro de 2018, com 83,04\% do eleitorado tendo comparecido às urnas, 5,7 milhões de votos válidos, 472.097 nulos e 448.289 em branco, sendo que 766 candidatos disputaram as 54 cadeiras da Assembleia Legislativa do Paraná (ALEP). Considerando os resultados dos pleitos de 2014 e de 2018, percebemos um declínio de partidos que mantinham certo predomínio, como os partidos Movimento Democrático Brasileiro (MDB) e da Social Democracia Brasileira (PSDB), que perderam 6 e 4 cadeiras, respectivamente. Por outro lado, o Partido Social Liberal (PSL) ascendeu de 1 para 8 deputados eleitos, possivelmente pelo fato desta ser a legenda do presidente constituído, Jair Bolsonaro, como também pelos 427.749 votos obtidos pelo candidato Delegado Francischini, que garantiu, por meio do quociente partidário, quatro cadeiras na 
ALEP para o partido, elegendo candidatos como o Subtenente Everton, que alcançou apenas 13.047 votos (PEREIRA, 2018). Ao se debruçar diante dos candidatos que participaram do pleito, esta pesquisa se propôs a identificar os elementos religiosos empregados por aqueles que se configuram como religiosos políticos, procurando perceber as estratégias de campanha para conquistar o eleitorado e fundamentar suas pautas e programas de governo.

Dentre os 766 candidatos que disputaram os cargos para deputado estadual no Paraná, buscamos identificar e analisar os religiosos políticos, tendo como lócus de análise suas fanpages na mídia social Facebook. A escolha desta se justifica pela vantagem numérica de usuários que a utilizam ${ }^{3}$, constituindo um espaço de discussão e compartilhamento de opiniões e notícias. A facilidade e praticidade para publicar e compartilhar materiais contribui para que esta mídia social seja amplamente utilizada durante o período eleitoral, oferecendo a possibilidade de recrutar simpatizantes que podem, por meio de seus perfis pessoais, difundir materiais e propostas, alcançando um público diversificado, o que não seria passível de ser realizado apenas com as mídias tradicionais, como o rádio e a televisão. Por fim, o Facebook, no entendimento de Aggio e Reis (2013), ocupa uma função relevante na ecologia de fluxos de informação online, com a possibilidade de receber materiais de outras mídias sociais, como o Twitter, Youtube, Instagran, entre outras, ampliando a integração e visibilidade das publicações.

Após um processo de refinamento que procurou, por meio das postagens nas fanpages, selecionar somente aqueles que realizam uso intenso de elementos religiosos em campanha - uso de versículos bíblicos, titulação religiosa, apoio institucional, participação em cultos, pautas de cunho moral, linguajar gospel, entre outros -, identificamos 37 religiosos políticos, dos quais 27 são evangélicos, 8 católicos e 2 de religiões de matriz afro. Após essa seleção, foram coletadas as publicações desses candidatos, reunindo fotos, vídeos, flyers, "santinhos", lives, jingles, posts, entre outros materiais que se apresentassem relevantes, a fim de traçar as principais frentes de campanha utilizadas durante o pleito.

Por fim, para esse artigo, selecionamos seis candidatos oriundos de vertentes pentecostais e neopentecostais consagradas no meio religioso, que

O Facebook é utilizado, segundo os dados da Pesquisa Brasileira de Mídia 2015, por 83\% do total de usuários que possuem acesso a mídias sociais, sendo a rede social online mais popular entre os brasileiros. Informações disponíveis em: < https://bit.ly/1FAvjZC $>$. Acesso em: 20 maio 2019. 
receberam apoio oficial de suas denominações durante suas campanhas. Compartilhamos da compreensão de que não é a religião em si, ou as indicações dos líderes religiosos que impulsionam a campanha desses políticos, mas o apoio da instituição religiosa, que é capaz de oferecer poder organizacional e financeiro sem uma série de constrangimentos, que dificilmente estaria disponível dentro dos partidos políticos (PRANDI; SANTOS; BONATO, 2019). Assim, conforme apresentado no Quadro 1, foram analisadas as campanhas dos religiosos políticos Cantora Mara Lima e Misael Junior, ambos da Assembleia de Deus (AD); Gilson de Souza, pertencente à Igreja do Evangelho Quadrangular (IEQ); Alexandre Amaro, da Igreja Universal do Reino de Deus (IURD); Missionário Ricardo Arruda, da Igreja Mundial do Poder de Deus (IMPD); e Dra. Andreza Albuquerque, da Igreja Internacional da Graça de Deus (IIGD). Esses, além de contarem com apoio oficial de suas denominações, acionaram elementos religiosos com ênfase e constância durante o período eleitoral de 2018.

Quadro 1: Religiosos políticos participantes da campanha para ALEP em 2018

\begin{tabular}{|c|c|c|c|c|c|}
\hline Candidato & Partido & Denominação & Título & Votação & Situação \\
\hline Alexandre Amaro & PRB & IURD & Pastor & 49.565 & Eleito \\
\hline Gilson de Souza & PSC & IEQ & Pastor & 46.116 & Reeleito \\
\hline Cantora Mara Lima & PSC & $\mathrm{AD}$ & Cantora & 33.866 & Suplente $^{1}$ \\
\hline $\begin{array}{l}\text { Missionário Ricardo } \\
\text { Arruda }\end{array}$ & PSL & IMPD & Missionário & 27.574 & Reeleito \\
\hline Misael Junior & PSC & $\mathrm{AD}$ & Presbítero & 12.195 & Suplente \\
\hline $\begin{array}{l}\text { Dra. Andreza } \\
\text { Albuquerque }\end{array}$ & PSD & IIGD & Membra $^{2}$ & 11.166 & Suplente \\
\hline
\end{tabular}

Fonte: Dados da pesquisa.

Após os procedimentos metodológicos de identificação e seleção dos religiosos políticos e a coleta dos materiais divulgados no Facebook, percebemos a utilização de algumas estratégias, pautas e recorrência ao

\footnotetext{
A suplente Mara Lima (PSC) assumiu, no dia 01 de fevereiro de 2019, o cargo de deputada estadual no lugar do eleito Guto Silva (PSD), que foi chamado pelo governador eleito, Ratinho Júnior, para assumir a Casa Civil do Paraná. Disponível em: <http://bit.ly/2JlKXxk>. Acesso em: 27 mar. 2019.

2 A candidata não possui titulação eclesiástica, mas exerce a função de líder estadual do Ministério Mulheres que Vencem, da Igreja Internacional da Graça de Deus.
} 
sagrado em comum entre os candidatos. Com isso em mente, construímos três eixos de análise em que podemos problematizar como os elementos religiosos foram tematizados ao longo das campanhas, atraindo eleitores e afirmando parecerias e vinculações. Primeiramente, abordamos como são manifestos os apoios dados pelas denominações religiosas, verdadeiras bênçãos institucionais, proporcionando espaço exclusivo em cultos e cerimônias, apoio de lideranças e personalidades de destaque, como cantores gospels, bem como capital simbólico e financeiro para as campanhas. Logo em seguida, apresentamos os elementos religiosos expressos em materiais de campanha, seja nos santinhos ou em flyers e vídeos, podendo exercer a dupla função de exibir o candidato como alguém que prioriza os princípios cristãos, como também de manter sua imagem sempre visível no feed de notícias de seus seguidores. Por fim, analisamos as pautas de teor moral cristão, observando como esses religiosos políticos utilizam do pleito como forma de apresentar seus projetos religiosos, geralmente como principal bandeira de campanha.

Num clima de batalha contra o mal, os candidatos propunham suas pautas para defender a família, o evangelho, os valores cristãos e contra uma "agenda comunista", que supostamente quer destruir a família tradicional, corromper as crianças e jovens e liberar o aborto e as drogas indiscriminadamente. Exemplo disso está em uma fala da candidata Carla Pimentel (PSC), membra da Igreja Assembleia de Deus, em uma de suas lives, quando cita o hino 212 da Harpa Cristã: “os guerreiros se preparam para a grande luta', e essa canção traduz o meu coração falando desse pleito. Eu acredito que é tempo da gente se levantar, pra guerrear, pra trazer de volta o valor da nossa nação". Esse discurso permeia, em grande medida, os eixos de análise das campanhas eleitorais, seja pelas pautas morais, nos flyers e "santinhos", ou pelo apoio institucional das denominações. Se já sabemos quem são os que dizem ser "enviados por Deus", escolhidos por Ele, agora observaremos, a seguir, como esses "pelejam em nome do Senhor".

\section{"Revesti-vos de toda a armadura de Deus": as "bênçãos" institucionais}

Os candidatos analisados por este trabalho obtiveram apoio oficial das denominações das quais fazem parte, o que possibilitou o constante uso das bênçãos institucionais durante as campanhas. Estas eram manifestas nas visitas aos templos, quando ocupavam posições de destaque nos púlpitos, geralmente recebendo orações e a oportunidade de discursarem ao público de fiéis, como também por meio apoios de personalidades do meio gospel, como líderes 
religiosos, pregadores e cantores. É perceptível que as denominações da vertente evangélica se destacam no cenário brasileiro como as que mais procuram estabelecer regras de conduta fora do meio religioso (PRANDI; SANTOS; BONATO, 2019), característica que se revela também durante o período eleitoral. Como pondera Guadalupe (2018), o êxito adquirido pelos evangélicos é consequência do apoio dado às candidaturas oficiais, apresentando um modelo de representação corporativo, principalmente das igrejas (neo)pentecostais, o que permite concentrar os votos dos fiéis destas denominações. O autor ainda destaca não ser possível observar um voto confessional no Brasil, mas, entre a vasta diversidade de evangélicos que adentram a arena política, geralmente conquistam êxito aqueles que possuem suporte denominacional.

Dentre as bênçãos concedidas pela denominação, as visitas às igrejas representaram espaço privilegiado, considerando que na maioria das vezes os religiosos políticos receberam oportunidade para ministrar ao público de fiéis, gozando das recomendações do líder da comunidade. É preciso destacar que, embora as indicações pastorais não garantam a certeza da conquista de eleitores, sua representação como autoridade espiritual aspira confiabilidade, característica essa que também é transmitida no seu papel como militante do candidato da denominação (SANTOS, 2013). Essas participações forneciam um espaço privilegiado para esses políticos, principalmente àqueles que já possuíam certa visibilidade dentro de suas instituições, como no caso das candidatas Cantora Mara Lima e de Dra. Andreza Albuquerque. Mesmo que os púlpitos não sejam utilizados para proselitismo político, ação proibida pelo artigo 37 da Lei 9.504/97, as participações dos religiosos políticos como cantores, pregadores ou líderes de comunidades (Imagem 1) possibilitam a criação de vínculos de confiança com os fiéis, bem como acesso às redes de sociabilidade criadas no interior das denominações. Com isso, o candidato pode alcançar um público mais amplo do que seria possível apenas com sua vinculação partidária, assim como se torna capaz de granjear "cabos eleitorais" voluntários para divulgação eleitoral (PRANDI; SANTOS; BONATO, 2019; SANTOS, 2013).

Figura 1: Religiosos políticos utilizando o púlpito para ministrações e louvor
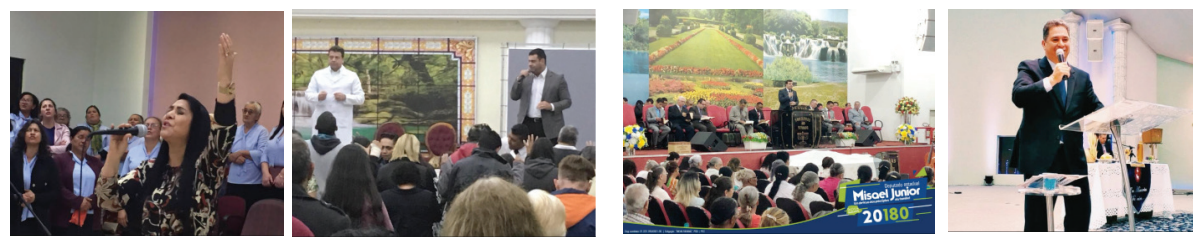

Fonte: Acervo do Grupo de Pesquisa Cultura e Relações de Poder. 
Outro benefício granjeado pelos candidatos oficiais das instituições religiosas foi a diferença no status daqueles que hipotecavam apoio a suas campanhas. Aqueles religiosos políticos que pertencem a igrejas menores, ou que não foram oficializados pelas suas denominações, apresentam indicações de pastores locais, que não possuem capital simbólico expressivo. Contudo, personalidades como a Cantora Mara Lima, além de receber apoio da Convenção das Igrejas Evangélicas da Assembleia de Deus do Paraná (CIEADEP), também recebeu indicações de pastores que são referência no meio pentecostal, entre os quais Pastor Silas Malafaia, Bispo Samuel Ferreira e as cantoras Suellen Lima, Cristina Mel, Vanilda Bordieri e Damares Oliveira. Esse foi também o caso de Alexandre Amaro, Gilson de Souza e Misael Junior, que receberam apoio de diversos pastores e bispos (Imagem 2), por meio de vídeos de indicação, publicados na página dos candidatos. Dra. Andreza Albuquerque recebeu validação do Missionário Romildo Ribeiro Soares (R. R. Soares, fundador da IIGD) que afirmou: "eu pedi [...] à Dra. Andreza Albuquerque para ser deputada estadual. Ajude-me! Eu to falando a verdade, foi eu quem pediu a eles para que fossem candidatos". O uso de patronos, aliados e lideranças procura atribuir prestígio, visibilidade e credibilidade à imagem do candidato, que por vezes não goza do mesmo capital simbólico que seu apoiador (MASSUCHIN; TAVARES, 2014). Vale ressaltar que, ao oferecer apoio aos religiosos políticos, esses agentes costumam afirmar que seu representante está apto para lutar contra as forças do mal que estão instauradas na política, manifestas em propostas contrárias à moral cristã numa visão maniqueísta da luta entre Deus e seus anjos contra Satanás e seus demônios, numa batalha espiritual que prolonga seus efeitos no campo material (MEZZOMO; PÁTARO; ONOFRE, 2014; MARIANO, 2003).

Contudo, houve alguns acréscimos nessa estratégia, indicando que os religiosos políticos não restringem suas campanhas somente ao espaço dos templos, mas se utilizam de outros meios, objetivando expandir seu nicho eleitoral. Esse foi o caso de Misael Junior, que passou a ser apresentado nos vários templos da Assembleia de Deus no Paraná, além de recorrer ao capital familiar de seu avô ${ }^{4}$, que goza de prestígio fora da AD. Outro

\footnotetext{
4 O candidato é neto do pastor José Pereira de Almeida (In Memorian), que foi pastor presidente da Assembleia de Deus em Astorga (1953-1961), Cruzeiro do Oeste (19611967), Umuarama (1967-1976) e Cascavel (1976-2006) e, também, um dos fundadores da Convenção das Igrejas Evangélicas da Assembleia de Deus no Estado do Paraná (CIEADEP).
} 
destaque está na experiência de Alexandre Amaro, que não concentrou sua campanha somente nos templos de sua denominação, mas também foi para as ruas, realizou passeatas, evidenciando uma relação harmoniosa com o eleitorado, arriscando alguns gracejos, sempre apresentando-se muito alegre, o que parece ter alcançado boa aceitação do público, já que foi eleito. Ainda, diferente do pleito de 2014, o candidato Missionário Ricardo Arruda não recorreu à participação de cultos e apoio de líderes religiosos ${ }^{5}$, mas centrou sua campanha em ataques contra os partidos de esquerda e as supostas tentativas de impor suas ideologias nas escolas, beneficiando-se da onda anticomunista e antipetista (TATAGIBA, 2018). Este quadro indica que, embora os candidatos reconheçam a importância da aproximação com o campo religioso para ampliar seu potencial eleitoral (MEZZOMO; PÁTARO; BONINI, 2014), não se restringem somente a esse âmbito.

Figura 2: Apoio de lideranças evangélicas aos candidatos religiosos

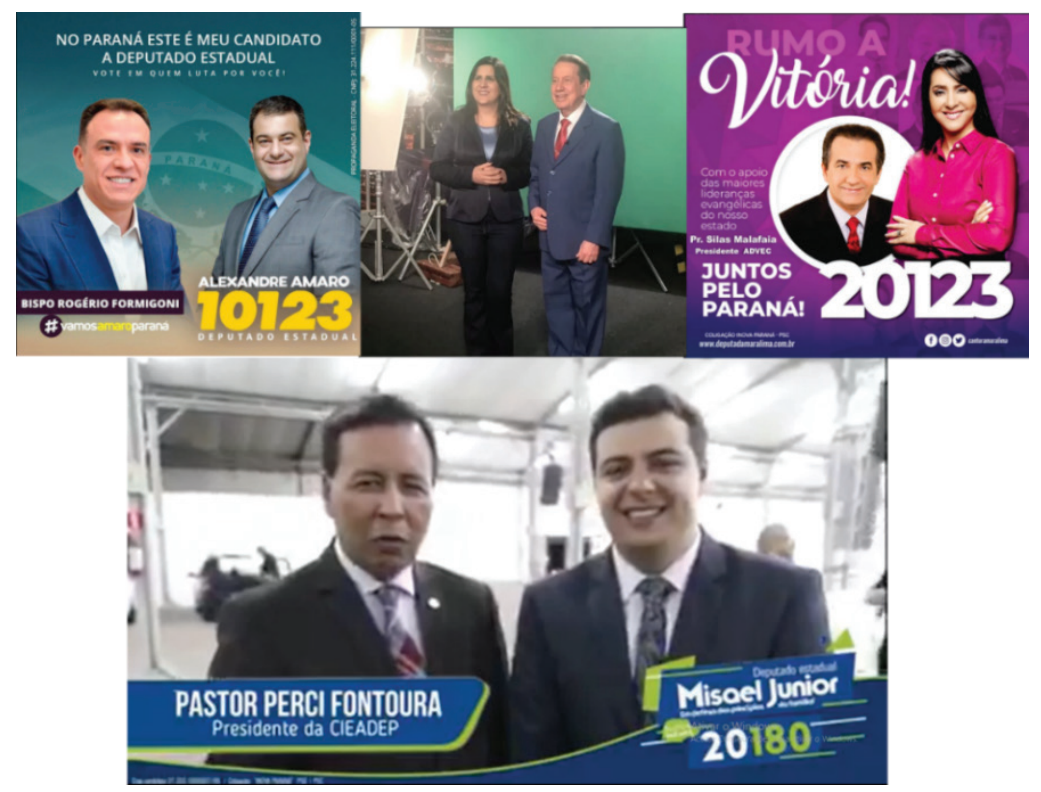

Fonte: Acervo do Grupo de Pesquisa Cultura e Relações de Poder.

Ao menos não publicizou essas visitas nas mídias sociais. 
Enfim, é possível observar que essas bênçãos institucionais ampliam a esfera de influência do candidato, passando a contar com poder organizacional e financeiro da denominação, que dispõe de mão de obra voluntária, ampla rede de contatos, isenção de impostos sobre o espaço físico e não precisam declarar a origem das doações recebidas (PRANDI; SANTOS; BONATO, 2019). Deste modo, os religiosos políticos buscam alcançar o público evangélico, seja com apoio das denominações, de lideranças ou de personalidades do meio gospel, podendo mesclar todas as formas acima mencionadas na mesma campanha, "revestindo-se de toda a armadura" para pelejar, utilizando não só das pautas como arma de combate, mas das instituições como elemento de base para divulgação, apoio financeiro e nicho eleitoral. Assim, é preciso questionar se tal participação desses agentes fere a legislação eleitoral, já que aparentam aproveitar-se "indevidamente da fé de seguidores para neles incutir a ideia - de modo direto ou subliminar - de que certo candidato é o que possui melhores atributos para lhes representar no desempenho de cargo eletivo" (VIEIRA et al., 2018), atentando contra a isonomia entre os candidatos, ferindo, de alguma forma, a legitimidade das eleições.

\section{"Então vocês verão novamente a diferença entre o justo e o ímpio": linguagem religiosa nos materiais de campanha}

O uso de um linguajar religioso em fyers e "santinhos", seja por meio de bordões, hashtags ou versículos, foram apresentados com constância nas publicações. A utilização desses elementos nas propagandas eleitorais tem a capacidade de reforçar a autoridade e legitimidade do discurso do candidato, assim como apresentar uma identidade que o vincule aos membros de determinado grupo do qual ambiciona o apoio (SEXUGI; MEZZOMO; PÁTARO, 2018). Dentre os candidatos analisados, foi notória a ênfase na família (Imagem 3), com bordões como "a deputada da família", "em defesa dos princípios da família", "em defesa da vida e da família”, entre outros. O termo "defesa", utilizado na maioria dos casos, traz em si a ideia de que a família e a vida estão sob ataque, numa batalha contra as forças do mal, que se utilizam de projetos que supostamente atentam contra os valores cristãos. Assim, esse posicionamento está presente em materiais que funcionam como cartão de visita do candidato, amplamente divulgados, diferenciando o justo, que luta pela família e pela vida, do ímpio, que supostamente se opõe a esses padrões. Esse uso demonstra a importância concedida pelos candidatos a essas pautas de teor moral, como um meio de atrair eleitores compatíveis com seus valores e princípios (SOUZA; ALMEIDA; OLIVEIRA, 2017). 
Figura 3: Santinhos de campanha - em defesa da família

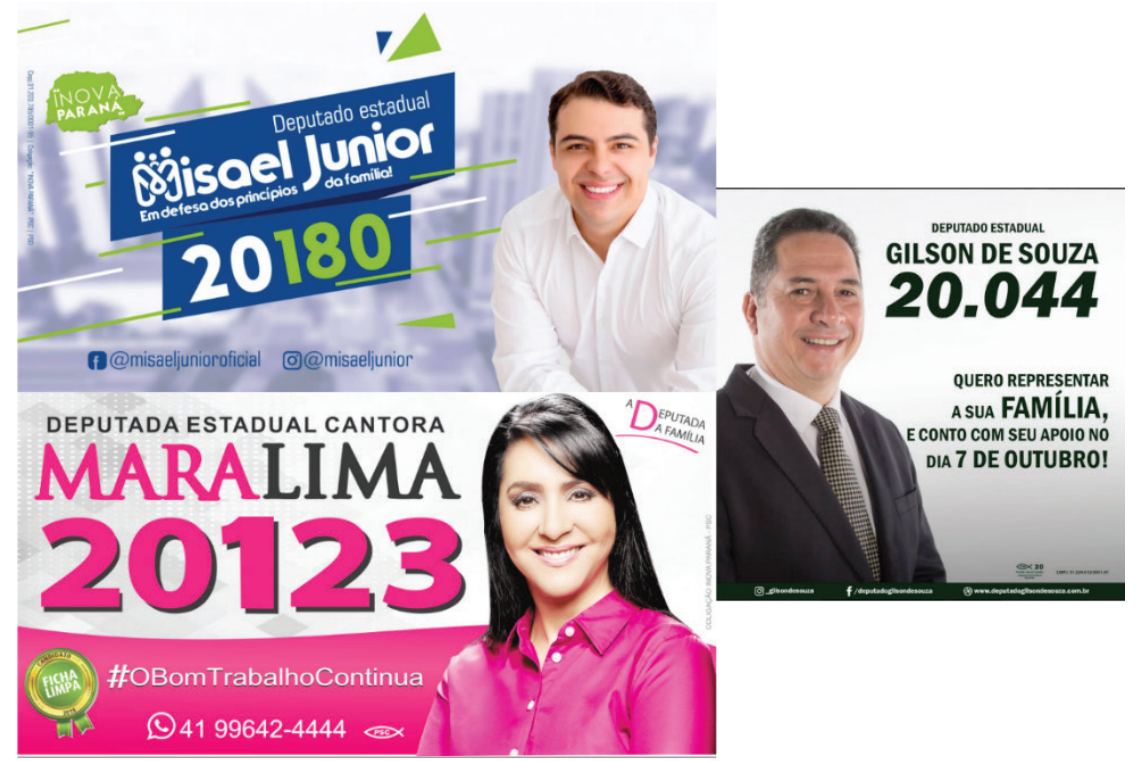

Fonte: Acervo do Grupo de Pesquisa Cultura e Relações de Poder.

Além dos santinhos, foram comuns as publicações de flyers e vídeos com versículos e textos religiosos. Como aponta Aggio e Reis (2013), com as campanhas executadas também nas mídias sociais, não só candidatos e partidos distribuem material, mas também os participantes das fanpages se tornam replicadores de informação. Com isso, há um aumento de fluxo de propaganda eleitoral, o que exige a elaboração de materiais atrativos e interativos, que reforcem a adesão política do membro. Isso é possível de ser observado nas postagens de Cantora Mara Lima que, diariamente, utilizou de vídeos curtos, de um minuto cada, nos quais tocavam pequenos trechos de músicas gospels gravados pela mesma, enquanto era exibido um flyer com um versículo. Também Alexandre Amaro realizou 70 dias de oração, produzindo vídeos com a duração de um minuto, diariamente, com seu nome e número de campanha ao fundo do vídeo, como pode ser percebido na Imagem 4. Com isso, esses candidatos realizam a manutenção da imagem de "candidato religioso", que está em constante contato com a "palavra de Deus", assim como garantem a presença constante na timeline de seus seguidores. 
Figura 4: Publicações diárias de Cantora Mara Lima e Alexandre Amaro

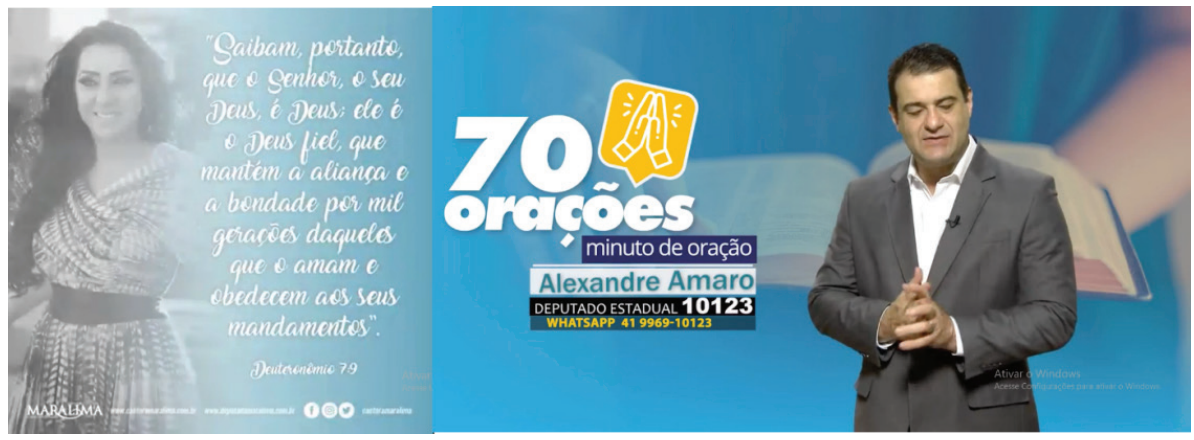

Fonte: Acervo do Grupo de Pesquisa Cultura e Relações de Poder.

Os outros candidatos compartilharam fyers com versículos, comumente acompanhado de elementos políticos, como número, nome de campanha e/ou foto do candidato (Figura 5), o que garante que sua imagem como candidato religioso alcance outras pessoas quando compartilhados pelos fiéis.

Figura 5: Flyers com versículos bíblicos

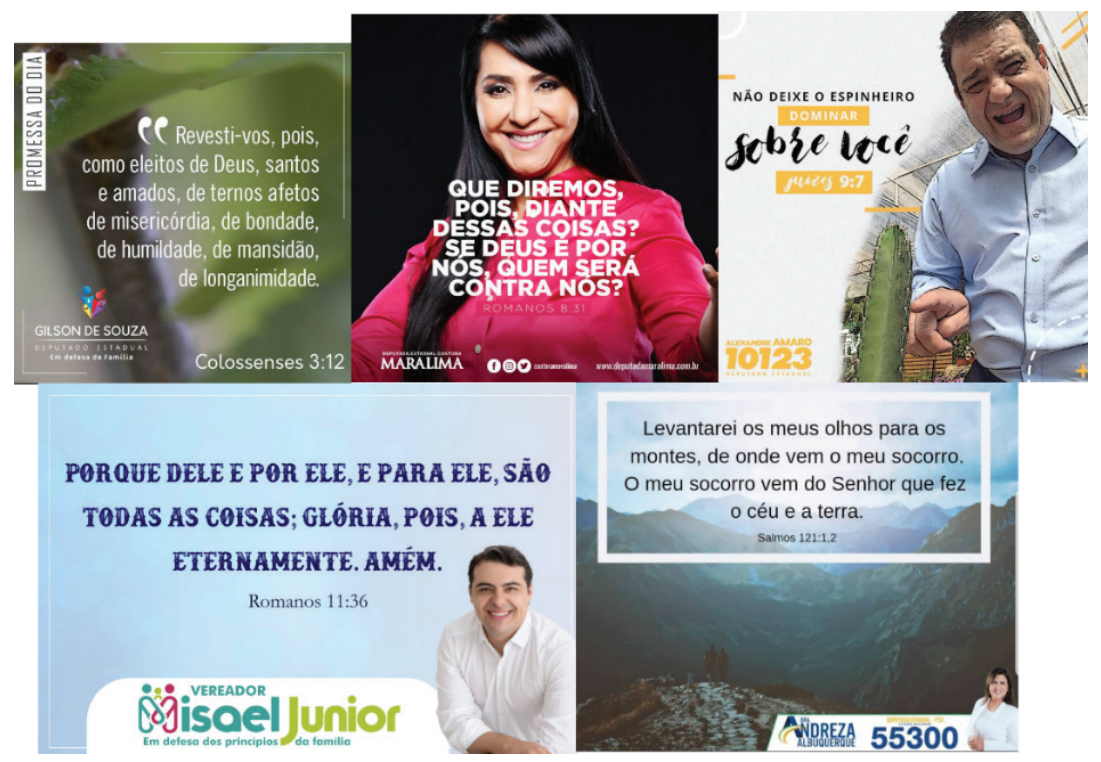

Fonte: Acervo do Grupo de Pesquisa Cultura e Relações de Poder. 
Esse material possui a possibilidade de ser compartilhado mesmo por aqueles que não intencionam realizar campanha para o político, mas o fazem ao replicá-los em seus perfis pessoais, graças aos textos religiosos, na maior parte das vezes versículos conhecidos. Esse tipo de publicação possui o benefício de manter o candidato sempre visível na timeline do seu seguidor, possui a capacidade de granjear novos membros fora do alcance da rede de contatos do candidato, além de possibilitar a interação entre eleitor e político, por meio dos comentários (AGGIO; REIS, 2013).

É importante notar que os materiais apresentam a ideia de batalha contra o mal, mesmo que por vezes sucintas. Palavras como "revesti-vos", "dominar", "socorro", "contra" e "defesa", presentes nos materiais, contribuem com a imagem de uma guerra, na qual os políticos devem se preparar e recorrer ao sagrado para vencê-la, sempre diferenciando os supostos justos dos ímpios. Sejam fyers ou "santinhos", esses documentos estampam, de forma saliente, como a religiosidade está presente na campanha e, possivelmente, será existente também na atuação dos eleitos, a partir de 2019.

\section{"O Senhor certamente fará um reino duradouro para ti, que travas os combates do Senhor": as pautas de cunho moral e religioso}

Os seis religiosos políticos abordados por este trabalho apresentaram, entre as suas propostas, pautas de teor moral, das quais se destacam a defesa da família e da vida. Por meio dessas, os candidatos procuram "conformar o ordenamento jurídico aos valores morais da 'maioria cristã', empreendendo cruzadas contra aborto, políticas igualitárias e anti-homofóbicas, educação sexual e a suposta doutrinação ideológica e de 'gênero' nas escolas" (MARIANO; GERARDI, 2019, p. 62). Para isso, as campanhas ganham um tom de luta contra as forças do mal, no qual os candidatos devem, como escolhidos de Deus, impedir que tais projetos sejam aprovados, procurando combater as alterações nos arranjos familiares, nas relações de gênero, nos valores morais, entre outras ações que busquem ampliar direitos e transformações liberalizantes (MARIANO, 2016). Esses posicionamentos orbitam em torno da mobilização de elementos religiosos, reivindicando a preservação dos valores cristãos, a manutenção da criminalização do aborto, a continuidade do modelo de família heteronormativa nuclear - classificada como a instituída por Deus - e a conservação da inocência de crianças e jovens, supostamente atacadas por influências de ideologias de partidos de esquerda. 
Os posicionamentos em favor da legalização do aborto e das drogas, bem como projetos como o Escola sem Homofobia, são considerados pelos religiosos políticos como algo imoral, advindo do maligno, por ameaçarem a hegemonia da moral cristã. Deste modo, apresentando-se, conforme lembra Mariano (2016, p. 721), como "servos diletos do Senhor dos Exércitos e militando em sua tropa à frente de um sem-número de batalhas espirituais (e morais, políticas e ideológicas)", os candidatos buscam demonizar as pautas opostas aos valores cristãos. Esse teor bélico é perceptível nas falas, como no caso de Alexandre Amaro, da IURD, quando afirma: "sou cristão, e vou lutar por aquilo que verdadeiramente acredito, a família é a minha principal bandeira", demonstrando que a prioridade estará em preservar a família dita tradicional. O Bispo Vagner Negrão, da mesma Igreja, quando gravou vídeo de apoio ao candidato diz: "temos certeza que ele, como deputado estadual, vai lutar, tem capacidade de lutar contra esses projetos, contra a destruição de nossas famílias, destruição das crianças". Desta forma, utilizam-se dessas propostas como principal frente, objetivando restaurar a ordem moral e social baseada nos conceitos cristãos que, supostamente, são constantemente atacados por forçar malignas (MARIANO; GERARDI, 2019).

A defesa da família foi um dos principais conceitos-chave utilizados em campanha pelos religiosos políticos analisados. Os autointitulados "representantes da família", Cantora Mara Lima e Misael Junior, apresentam esse conceito como uma verdade absoluta, conhecida pelo seu público, atribuindo, nas falas e flyers, o destaque principal à posição de defensor dessa instituição. Isso pode ser visto nos posts de Alexandre Amaro, afirmando que os "valores da família são de vital importância na nossa sociedade e protegêe-los é muito mais que um dever, é uma missão". Também publicaram Missionário Ricardo Arruda: "enquanto estiver vivo, lutarei a favor dos valores da família e em prol da boa educação das nossas crianças" e Gilson de Souza: "A família é a base da formação de todo cidadão! Continuaremos a construir um Paraná que valoriza e preserva os valores da família para os paranaenses!”. As palavras grifadas por nós indicam a característica bélica que as campanhas assumiram, principalmente quando abordavam pautas baseadas nos fundamentos cristãos, reproduzindo a ideia de uma batalha contra o mal.

Mesmo que os candidatos não declarem abertamente qual é o modelo de família ${ }^{6}$ que defendem, é possível inferir que se trata do mesmo modelo

${ }_{6}$ Os candidatos não apresentaram, em campanha, qual o modelo de família que buscam defender. Contudo, em alguns momentos, utilizaram termos como "família cristã" e "família tradicional brasileira". 
proposto no Projeto de Lei n ${ }^{\circ}$ 6.583, de 2013, denominado Estatuto da Família, de autoria do Deputado Federal Anderson Ferreira (PR-PE). Segundo este, a entidade familiar é definida como "o núcleo social formado a partir da união entre um homem e uma mulher, por meio de casamento ou união estável, ou ainda por comunidade formada por qualquer dos pais e seus descendentes (BRASIL, 2013, negrito no original). Esse modelo é apresentado, de forma discreta, nos fyers dos candidatos Gilson de Souza e Alexandre Amaro, que aparecem acompanhados de suas esposas, como também no material de Missionário Ricardo Arruda, no qual afirma defender a família tradicional (Imagem 6). Novamente, destaca-se o teor bélico nas afirmações, como no fyer de Dra. Andreza Albuquerque, afirmando lutar contra "a destruição das nossas famílias". Partindo dessa posição, compreendemos que esses religiosos políticos buscam combater qualquer pauta ou proposta que disponibilize direitos a outros modelos de família que seja diferente da "entidade matrimonializada, patriarcal, patrimonializada, indissolúvel, hierarquizada e heterossexual" (DIAS, 2005, p. 5), paradigma antipluralista cristão.

Figura 6: Defesa da Família nos materiais de campanha

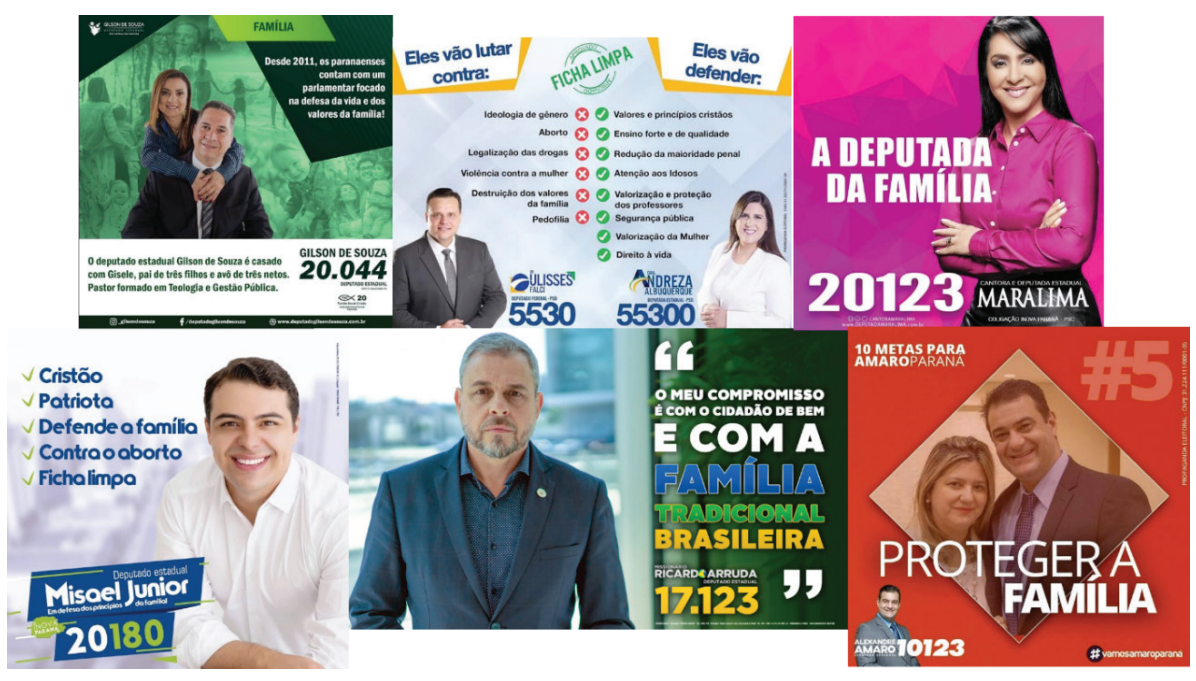

Fonte: Acervo do Grupo de Pesquisa Cultura e Relações de Poder.

A luta contra a denominada "ideologia de gênero" e a suposta doutrinação política e ideológica nas escolas também estiveram presentes 
nos discursos desses candidatos que, durante a campanha, a associaram com a pedofilia, gastos com dinheiro público e condução das crianças à homossexualidade. É preciso destacar, logo de início, que o termo "ideologia de gênero" é a maneira fantasiosa e deturpada dos religiosos políticos expressarem "os mais que necessários estudos e diálogos sobre a justiça e igualdade de gênero" (MARANHÃO FILHO, 2019, p. 319). Na fala do Missionário R. R. Soares, na ocasião de hipotecar irrestrito apoio à candidata da Igreja, Dra. Andreza Albuquerque, é possível observar como é apresentada a discussão durante o pleito, geralmente de caráter maniqueísta: “o pessoal do mal quer fazer leis que são uma verdadeira vergonha, querem convencer os meninos de 4, 5, 8 anos, por aí, que eles podem ser meninas, e que as meninas podem ter nascido errado e são meninos". Também o Bispo Vagner Negrão, que concedeu apoio a Alexandre Amaro, fala sobre um ataque para destruir as famílias e as crianças, fundamentando sua opinião em dados que geram certo espanto, contudo sem apresentar fontes:

Nós gostaríamos de falar com todos, nesse momento, a respeito dessa situação em que nós estamos vivendo, um momento crítico em todo o país, que querem destruir as nossas crianças, querem destruir as famílias! Nós temos reportagens que mostram que nos países aonde, por exemplo, a ideologia de gênero foi aprovada, já subiu espantosamente... na Inglaterra, por exemplo, $4500 \%$ o número de crianças fazendo tratamento para mudança de sexo, e já tem sido provado que isso é desastroso, tem trazido sofrimento, automutilação, suicídio, isso não funciona! [...] temos certeza que ele [Alexandre Amaro] como deputado estadual vai lutar, tem capacidade de lutar contra esses projetos, contra a destruição de nossa família, destruição das crianças.

Também a cantora Mara Lima, entre as realizações do seu mandato anterior, alega que "barrou a ideologia de gênero, barrou a 'cartilha do sexo', disse não ao aborto, disse não à legalização das drogas”. A justificativa utilizada com maior ênfase pelos religiosos políticos aqui analisados está fundamentada na ideia de que as discussões sobre igualdade de gênero nas escolas são, na verdade, uma forma de erotizar as crianças, incentivando-as a realizar relações sexuais, o que fomentaria a pedofilia. Partindo deste princípio, Misael Junior afirmou: "sou contra a ideologia de gênero, [...] sou contra todo material didático que é levado a escolas e que deturpam a inocência das nossas crianças. Eu não posso aceitar que crianças tenha contato com erotismo, com sexualidade antes do momento certo, acho que isso é o dever dos pais". O 
material, nomeado pelos candidatos como Kit Gay ou "cartilha do sexo", é um conjunto de instrumentos didáticos-pedagógicos, criados no intuito de desconstruir estereótipos atribuídos aos grupos $\mathrm{LTBQ}^{+}$, contribuindo para alterar as noções dicotômicas de gênero e sexualidade, objetivando diminuir a homofobia e o desrespeito (OLIVEIRA JUNIOR; MAIO, 2017). O Kit de combate e prevenção à homofobia faz parte do projeto governamental Escola sem Homofobia, e sobre este ponto é construído outro argumento utilizado pelos candidatos: de que o investimento de dinheiro e mão de obra pública estariam sendo utilizados para corromper as crianças. Sobre isso, Gilson de Souza pondera: "estamos vendo uma força muito grande, dinheiro sendo investido, material humano sendo investido, para tentar confundir as nossas crianças, quanto a sua fé, quanto a sua sexualidade, [...] e nós combatemos isso". Ainda, Misael Junior diz em seu material com propostas de campanha: "combater com veemência a ideologia de gênero e uso de dinheiro público em projetos que ameaçam a moral e a decência das famílias, de modo a não permitir o acesso das crianças a conteúdos pornográficos".

Durante a campanha, a ideia reproduzida pelos candidatos não estava centrada em reprimir diretamente movimentos LGBT+, mas defender as crianças de influências da escola e das mídias - em especial, a Rede Globo - que, segundo os religiosos políticos, estariam doutrinando os mancebos. Essa posição é perceptível na fala de Missionário Ricardo Arruda, ao afirmar: "não é normal isso gente! Isso foge à regra! Aqui não tem nenhum ditador, ninguém aqui é homofóbico, a pessoa quando for maior de idade escolhe o caminho que ela quiser, ninguém vai lhe obrigar a fazer nada, cuide da sua vida e seja feliz, agora mexer com criança não! Isso é crime!". O mesmo afirmou, durante fala no plenário: "veja a incoerência, rede Globo põe novela com pornografia para qualquer um ver e a cartilha para criança que ela defende não pode ser vista porque é imprópria, tamanha incoerência, tamanha inversão de valores". Perceba que, embora o material tenha sido produzido objetivando alcançar alunos do ensino médio (OLIVEIRA JUNIOR; MAIO, 2017), esses religiosos políticos insistem em enfatizar crianças menores de 10 anos, como é possível observar na fala de Missionário Ricardo Arruda: "querem pegar os seus filhos de 6 anos de idade [...] e falar assim 'você é menina? Você pode virar menino, você é menino? Você pode ver a menina'. Aí quer por um para abraçar o outro, beijar o outro. Gente, é do mal isso aí, é maligno para formação dos nossos filhos". Esta ênfase nos parece ser uma estratégia para sensibilizar e granjear um público que compactue com 
esses posicionamentos. Nos fyers, é possível observar como os candidatos apresentam uma suposta corrupção das crianças, ora com imagens de crianças, objetivando sensibilizar, ou do próprio candidato, indicando que estes estão trabalhando contra essas ideologias (Imagem 7).

Figura 7: Ideologia de gênero e Escola sem Partido nos materiais de campanha

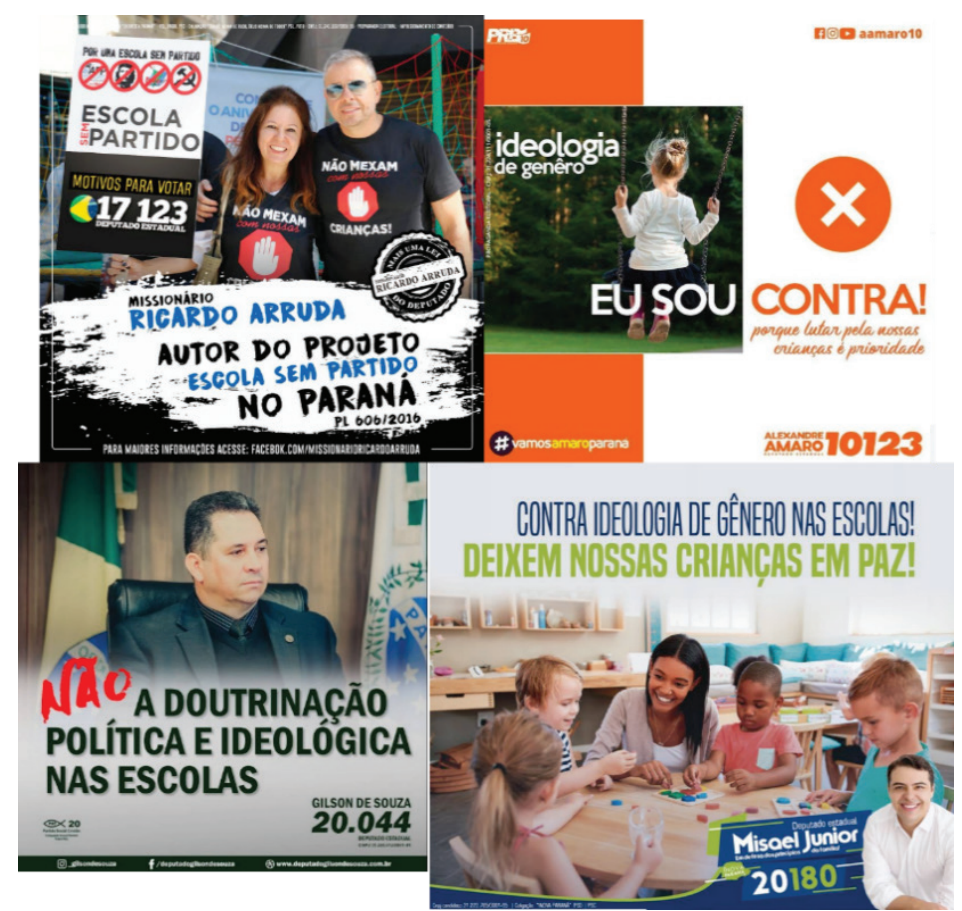

Fonte: Acervo do Grupo de Pesquisa Cultura e Relações de Poder.

Se o ataque às crianças se dá nas escolas, o contra-ataque ocorre no mesmo ambiente. Em 2015, Gilson de Souza e mais 11 deputados estaduais - dentre os quais destacamos Cantora Mara Lima, Missionário Ricardo Arruda e Pastor Edson Praczyk ${ }^{7}$ - apresentaram o Projeto de Lei

O Pastor Edson Praczyk foi deputado estadual durante cinco mandatos, apoiado pela Igreja Universal do Reino de Deus. No pleito de 2018, foi substituído pelo candidato Alexandre Amaro. Embora o motivo da troca não tenha sido revelado, é possível que esteja relacionado as denúncias de contratação de funcionários fantasmas ligados à denominação e desvio de salários. Mais informações, consultar https://glo.bo/2yswDOI. Acesso em: 13 jun. 2019. 
748/2015, denominado Escola sem Partido (ESP), que objetiva "coibir aquilo que entendem por doutrinação política e ideológica em sala de aula (MEZZOMO, 2018, p. 381). O projeto foi arquivado, possivelmente pela repercussão negativa que alcançou na época. Contudo, em 2016, um novo projeto foi proposto pelos deputados Missionário Ricardo Arruda e Felipe Francischini, o PL 606/2016, que traz poucas modificações em relação ao primeiro. Sobre o projeto, seu autor argumenta:

Pessoal acompanhe a guerra que estamos vivendo no nosso Brasil, da maldita esquerda comunista contra a direita conservadora. No que tange a educação, veja a grande diferença entre a direita conservadora que quer o melhor para o povo brasileiro, e a maldita esquerda que quer destruir as famílias e o povo brasileiro [...] o projeto da direita conservadora, aqui no Paraná eu represento a direita conservadora, o meu projeto é o Escola Sem Partido, que proíbe a ideologia partidária e de gênero, porque não podemos admitir que um professor em sala de aula pegue uma criança de seis anos de idade e fale para ela: 'você é menina? Pode virar menino, você é menino? Pode virar menina'. É claro que nenhum pai quer isso para os seus filhos, quem educa é o pai, quem educa as crianças são os pais e não o professor (MISSIONÁRIO RICARDO ARRUDA, 2018).

O candidato da IMPD utilizou do PL 606/2016, durante a campanha, como instrumento de luta contra "a maldita esquerda que quer destruir as famílias e o povo brasileiro". Em seu primeiro parágrafo, o projeto menciona de forma explicita a posição contra a denominada "ideologia de gênero": "O Poder público não se imiscuirá na orientação sexual dos alunos nem permitirá qualquer prática capaz de comprometer ou direcionar o natural desenvolvimento de sua personalidade, em harmonia com a respectiva identidade biológica de sexo, sendo vedada, especialmente, a aplicação dos postulados da ideologia de gênero" (Art. 1, Parágrafo único, PL 606/2016, ALEP). Também foi reservado um artigo do projeto a fim de proibir a "prática de doutrinação política e ideológica bem como a veiculação de conteúdo ou a realização de atividade de cunho religioso ou moral que possam estar em conflito com as convicções dos pais ou responsáveis pelos estudantes" (Art. 2, PL 606/2016, ALEP). Por fim, define que o professor "não se aproveitará da audiência cativa dos alunos, para promover suas próprias opiniões, concepções ou preferências ideológicas, morais, políticas e partidárias” (Art. 3, Item I, PL 606/2016, ALEP). Deste modo, é possível inferir que o projeto apresenta "tentativas de reforçar a autoridade familiar na 
educação das crianças e restringir a autonomia dos professores e as temáticas trabalhadas em sala de aula" (SANTOS, 2018, p. 122).

Por fim, outra pauta moral que recebeu destaque durante a campanha foram aquelas voltadas à manutenção da criminalização do aborto, comumente denominada "Defesa da Vida". Nos fyers publicados (Imagem 8), a maternidade é exibida como algo sagrado, um dom de Deus, que deve ser preservado, expondo o nascituro como algo frágil e indefeso, que precisa ser protegido. Esse tipo de material objetiva sensibilizar o público, humanizar o feto, e transformar a interrupção da gravidez em algo moralmente cruel (MONTERO; SILVA; SALES, 2018). Também são apresentadas imagens que remetem diretamente o aborto a um assassinato, e que, de forma implícita, aponta a mulher que interrompe a gravidez como assassina (PINHEIRO; SILVA, 2018). Geralmente, a mulher é desvinculada da imagem do feto, buscando demonstrar que são dois corpos diferentes, a fim de deslegitimar o direito da primeira sobre seu próprio corpo. Com isso, objetivam retirar a independência da gestante, autonomia essa que confronta com a ideia do nascituro como criação divina, que não deve ser interferida (MARIANO; BIROLI, 2017).

Figura 8: Defesa da vida nos materiais de campanha

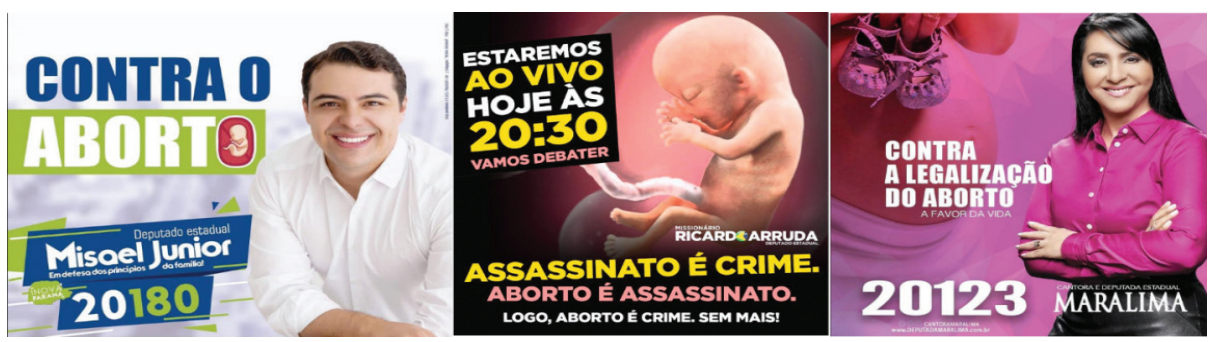

Fonte: Acervo do Grupo de Pesquisa Cultura e Relações de Poder.

Além dessas, outras propostas específicas de alguns candidatos também estiveram relacionadas à religião, como no caso de Misael Junior, que propôs a criação da "Escola Assembleiana de Ensino, atendendo a proposta da CGADB", além do fornecimento de "suporte e destinação de recursos para assistência social das Igrejas para compras de instrumentos, computadores, manutenção, creches e escolas e afins". Desta forma, como ponderam alguns autores, a religião reconhece a importância da inserção no campo 
político para ampliar seu poder de atuação na sociedade, além de garantir benefícios do Estado para si (MEZZOMO; PÁTARO; BONINI, 2016; ORO; CARAVALHO JUNIOR, 2013; MACHADO, 2003).

Deste modo, foi possível perceber como esses candidatos fazem uso da sua posição eleitoral para propor suas pautas vinculadas à religião, geralmente voltadas para combater posicionamentos diferente daqueles baseados na moral cristã, assim como forma de obter benefícios estatais para a esfera religiosa. Ao considerar-se como representantes de Deus na política e membros fiéis de seu exército, batalham em defesa dos princípios da religião, em busca de alcançar um público eleitoral que compactua com seus posicionamentos. Nesta disputa, contudo, o posicionamento religioso afirma-se em detrimento dos direitos de liberdade de outros grupos, como mulheres (MACHADO, 2017), professores (MEZZOMO, 2018), religiões de matriz afro (CAMURÇA, 2017), grupos LGBTQIA (MISKOLCI; CAMPANA, 2017), entre outras. Assim, ao publicizar proposições de cunho moral atreladas a um caráter bélico, geralmente como principal bandeira de campanha, procuram solidificar não só as pautas, mas também seu "reino duradouro" na política, embora nem sempre o eleitorado eleja os que "travam as causas do Senhor".

\section{"Não há justo, nem um sequer": considerações finais}

Diante da vasta literatura sobre o tema e dos materiais coletados, é perceptível o uso do capital religioso durante as campanhas dos denominados religiosos políticos. Esses não só trazem sua linguagem, fé e cultura para o cenário eleitoral, como também apresentam suas pautas permeadas de valores cristãos, como a defesa da vida e da família, luta contra a "ideologia de gênero" e legalização das drogas, geralmente como sua principal bandeira. As estratégias de campanha que envolvem o sagrado não são veladas, mas utilizadas com formas e intensidades próprias a depender do candidato, seja nas titulações de urna, nas fotos ocupando locais de destaques nos templos, nos apoios das lideranças religiosas ou nos versículos em flyers e "santinhos". Desta forma, esses agentes procuram lutar contra as propostas que se opõem ao seu ethos, bem como legitimar suas pautas e persuadir o público evangélico a se tornar seu eleitor. A participação desses candidatos, utilizando de estratégias que expõem as demandas religiosas e de seu ethos, funciona como um modo de publicizar sua fé, conquistando visibilidade e espaço dentro da esfera pública, ação característica do modus operandi evangélico. Deste modo, construíram suas campanhas recorrendo a símbolos, discursos 
e apoio religiosos, fundamentado no tripé da teologia neopentecostal: batalha contra o mal, evangelho da prosperidade e a centralidade do tempo presente.

Ricardo Mariano (2016) pondera sobre o uso desse caráter bélico como estratégia dos religiosos políticos em campanha. O autor afirma, baseados nas ideias de Cristian Smith, que os evangélicos procuram construir uma identidade, buscando assegurar o compromisso e o engajamento de seus membros. Porém, ao fazê-lo, confronta com a diversidade, criando barreiras e tensões com outros grupos, produzindo uma identidade coletiva de combate. Assim, objetivam visibilizar suas causas, enfrentar aquilo que consideram como decadência e afronta à moral e os valores da religião, lançando candidatos militantes, procurando conformar a sociedade aos seus princípios. Isso resulta no lançamento de justos para combater os ímpios, sendo esse último todo aquele que se porta diferente daquilo que acreditam como certo. Essa retórica bélica e maniqueísta se torna uma eficiente estratégia pois despertam nos fiéis o medo de perder a liberdade religiosa, aliado ao sentimento de descriminação, produzindo soldados do exército do Senhor. Essa guerra entre o Bem e o Mal permeou em grande medida a campanha dos religiosos políticos aqui analisados.

Neste trabalho, construímos três eixos de análise, com base em elementos que foram recorrentes nos materiais de campanhas dos religiosos políticos que receberam apoio oficial de suas denominações. Primeiramente, observamos as visitas às igrejas, quando os candidatos recebiam apoio de líderes e autoridades espirituais, espaços para discursos - mesmo que não voltados explicitamente para assuntos eleitorais -, e acesso as redes de sociabilidade, além das indicações de cantores e pregadores renomados, que por vezes possuem o capital simbólico religioso maior que o de seu apadrinhado. Essas bênçãos institucionais ampliam a esfera de influência do político, granjeia cabos eleitorais voluntários para suas campanhas, reforça a rede de contatos e de eleitores, como também fornece espaço livre de impostos, estrutura que talvez não fosse possível somente por meio de partidos políticos. Logo em seguida, percebemos o uso de versículos e mensagens religiosas em flyers e santinhos, a fim de diferenciar o justo do ímpio, aqueles que defendem as causas do Senhor daqueles que lutam contra elas. Assim, objetivam criar e realizar a manutenção da identidade de cristãos escolhidos por Deus para guerrear contra o mal. Além disso, esse tipo de material, publicado com frequência, possibilita a que o candidato seja visto constantemente no feed de notícias dos eleitores, amplia seu 
alcance por meio de compartilhamentos e proporciona interação políticoeleitor via comentários. Por fim, se os candidatos se revestem da identidade de cristão e utilizam das instituições como principal base eleitoral, são as pautas morais uma de suas principais estratégias de ataque contra as forças do mal - manifestas em proposições contrárias a moral cristã -, com ênfase para a defesa da família e da vida, e contra a ideologia de gênero. Por meio dessas estratégias, buscam conquistar para si eleitores que compactue com suas propostas, assim como conformar a sociedade aos valores da religião.

Se o livro de provérbios diz que "quando se multiplicam os justos, o povo se alegra", cabe discutir quem são os "justos" e quem é o povo que se alegrará diante do governo daqueles que foram contemplados por esse artigo. Analisando as propostas que parecem restringir a liberdade da mulher, da comunidade LGBTQIA, de professores, das religiões não ligadas ao cristianismo, e qualquer outra forma de pensamento diferente da crença desses, nos parece não haver um justo sequer, já que essas minorias "suspiram", como quando "dominam os perversos" 8 . Finalmente, cabe destacar como as fronteiras entre os campos da religião e política não estão bem delimitadas, mas existem permeabilizações e imbricações, num modelo de laicidade distante daquele rígido e bem demarcado, o que possibilita a esses religiosos políticos trazerem para a cena pública suas pautas, embasados na célebre afirmação dita por candidatos e lideranças religiosas de que o "Estado é laico, mas não é ateu". Deste modo, a religião conserva sua luta pela manutenção de sua hegemonia na esfera pública, fundamentada nos valores cristãos - e ao que tudo indica continuarão engajados na militância -, que supostamente são defendidos pela maioria da sociedade, em detrimento de outros grupos, com discursos diferentes daqueles professados pelos "justos".

\section{Referências}

AGGIO, C.; REIS, L. Campanha eleitoral no Facebook: usos, configurações e o papel atribuído a esse site por três candidatos eleitos nas eleições municipais de 2012. Revista Compolítica, Rio de Janeiro, v. 2, n. 3, p. 155-188, jul./dez. 2013.

BISPO, R. Na corrente midiática da fé: comunicação de massa e dinâmicas contemporâneas do testemunho evangélico. Horizontes antropológicos, Porto Alegre, Ano 24, n. 52, p. 249-277, set./dez. 2018.

\footnotetext{
8 "Quando se multiplicam os justos, o povo se alegra, quando, porém, domina o perverso, o povo suspira”. BÍBLIA, A. T. Provérbios 29: 2. In: BÍBLIA SAGRADA: antigo e novo testamento. Tradução de João Ferreira de Almeida. Barueri: Sociedade Bíblica do Brasil, 2008. 1664p.
} 
BOSISIO, I. Religião, cultura, nação: articulações possíveis a partir de três datas comemorativas. Horizontes antropológicos, Porto Alegre, Ano 24, n. 52, p. 199-221, set./dez. 2018.

BRASIL. Congresso Nacional. Projeto de Lei PL 6583/2013. Dispõe sobre o Estatuto da Família e dá outras providências. Publicado em: 16 out. 2013. Disponível em: < http://bit. ly/30hPqIl>. Acesso em: 27 maio 2019.

BURITY, J. Republicanismo e o crescimento do papel público das religiões: comparando Brasil e Argentina. Contemporânea, São Carlos, v. 1, n. 1, p. 199-227, jan./jun. 2011.

CAMPOS, L. S. Evangélicos e política no Brasil: análise das eleições de 2002 a 2010 para a Câmara Federal. In: PÁTARO, C. S. O.; HAHN, F. A.; MEZZOMO, F. A. (Orgs.). Instituições e sociabilidades: religião, política e juventudes. Campo Mourão, PR: Editora Fecilcam, 2013.

CAMURÇA, M. A. A questão da laicidade no Brasil: mosaico de configurações e arena de controvérsias. Horizonte, Belo Horizonte, v. 15, n. 47, p. 855-886, jul./set. 2017.

CAMURÇA, M. A. Ciências Sociais e Ciências da Religião: polêmicas e interlocuções. São Paulo, SP: Paulinas, 2008.

CANCIAN, R. Conflito Igreja-Estado no período da ditadura militar: revisitando aspectos teóricos das abordagens institucionais. Angelus Novus, São Paulo, v. 7, n. 11, p. 95-116, 2016.

CARREIRO, G. S. Sobre a lógica do voto evangélico no Brasil: filiação religiosa e seu impacto na política brasileira. Século XXI, Santa Maria, v. 7, n. 2, p. 66-100, jul./dez. 2017

CARVALHO JUNIOR, E. T.; ORO, A. P. Eleições municipais 2016: religião e política nas capitais brasileiras. Debates do NER, Porto Alegre, Ano 18, n. 32, p. 15-68, jul./dez. 2017.

DATAFOLHA. 44\% dos evangélicos são ex-católicos. Publicado em: 28 dez. 2016. Disponível em: <http://bit.ly/2Jd0zV3>. Acesso em: 15 mar. 2019.

DIAS, M. B. Homoafetividade e o Direito à Diferença. Universo Jurídico, Juiz de Fora, Ano 11, 04 jul. 2005.

GIUMBELLI, E. Cultura pública: evangélicos e suas presença na sociedade brasileira. In: GIUMBELLI, E. Símbolos religiosos em controvérsias. São Paulo, SP: Terceiro Nome, 2014.

GUADALUPE, J. L. P. ¿Políticos Evangélicos o Evangélicos Políticos? Los nuevos modelos de conquista política de los evangélicos. In: GUADALUPE, J. L. P.; GRUNDBERGER, S. (Orgs.). Evangélicos y poder em América Latina. Lima: Instituto de Estudios Social Cristianos; Konrad Adenauer Stiftung, 2018.

IBGE. Censo demográfico 2010: características gerais da população, religião e pessoas com deficiência. Rio de Janeiro, RJ: IBGE, 2012.

LUNA, N. O julgamento no Supremo do aborto de anencéfalo - ADPF 54: uma etnografia da religião no espaço público. Horizontes antropológicos, Porto Alegre, Ano 24, n. 52, p. 165-197, set./dez. 2018.

MACHADO, L. Z. O aborto como direito e o aborto como crime: o retrocesso neoconservador. Cadernos Pagu, Campinas, s/v., n. 50, p. 1-48, maio/ago. 2017.

MACHADO, M. D. Existe um estilo evangélico de fazer política? In: BIRMAN, P. (Org.). Religião e espaço público. Brasília, DF: Attar Editorial, 2003. 
MACHADO, M. D.; BURITY, J. Política dos Pentecostais no Brasil na Avaliação de Líderes Religiosos. Dados, Rio de Janeiro, v. 57, n. 3, p. 601-631, jul./set. 2014.

MARANHÃO FILHO, E. M. A. "Um tapa na cara pra quem diz que cura gay não existe": ideologia de gênero e de gênesis em Cleycianne, Lady Gaga e Marco Feliciano. In: MARANHÃo FILHO, E. M. A. (Org.). Política, religião e diversidades: educação e espaço público (vol. 1). Florianópolis, SC: ABHR / Fogo, 2018.

MARIANO, R.; BIROLI, F. O debate sobre aborto na Câmara dos Deputados (1991-2014): posições e vozes das mulheres parlamentares. Cadernos Pagu, Campinas, s/v., n. 50, p. 1-38, set/dez. 2017.

MARIANO, R. Expansão e ativismo político de grupos evangélicos conservadores: secularismo e pluralismo em debate. Civitas, Porto Alegre, v. 16, n. 4, p. 710-728, out./dez. 2016.

MARIANO, R. Neopentecostais: sociologia do novo pentecostalismo no Brasil. São Paulo, SP: Edições Loyola, 2005.

MARIANO, R. Guerra espiritual: o protagonismo do diabo nos cultos neopentecostais. Debates do NER, Porto Alegre, Ano 4, n. 4, p. 21-34, jul. 2003.

MARIANO, R.; GERARDI, D. A. Eleições presidenciais na América latina em 2018 e ativismo político de evangélicos conservadores. Revista USP, São Paulo, n. 120, p. 61-76 jan./mar. 2019.

MASSUCHIN, M. G.; TAVARES, C. Q. Disputa eleitoral e estratégia de campanha na internet: padrões de uso dos websites pelos candidatos em 2012. Paraná Eleitoral, Curitiba, v. 3, n. 3, p. 437-472, set./dez. 2014.

MEZZOMO, F. A. Deputados evangélicos e o Programa Escola Sem Partido na Assembleia Legislativa do Estado do Paraná. In: MARANHÃO FILHO, E. M. A. (Org.). Política, religião e diversidades: educação e espaço público (vol. 1). Florianópolis, SC: ABHR / Fogo, 2018.

MEZZOMO, F. A.; PÁTARO, C. S. O. Religião e Política: estratégias institucionais e acionamentos religiosos por candidatos evangélicos em eleições proporcionais (2008-2016). Rever, São Paulo, Ano 17, n. 3, p. 139-165, set./dez. 2017.

MEZZOMO, F. A.; PÁTARO, C. S. O.; BONINI, L. F. G. Religião e política nas eleições ao legislativo municipal de Campo Mourão, Paraná. Debates do NER, Porto Alegre, Ano 15, n. 25, p. 271-289, jan./jun. 2014.

MEZZOMO, F. A.; PÁTARO, C. S. O. ONOFRE, L. Evangélicos na política: as eleições proporcionais de Campo Mourão em 2012. Rever, São Paulo, Ano 14, n. 2, p. 244-264, jul./ dez. 2014.

MEZZOMO, F. A.; PÁTARO, C. S. O.; PINHEIRO, A. C. O dia do "evangélico": estratégias e disputas para a visibilidade pública de religiões evangélicas. Mediações, Londrina, v. 24, n. 1, p. 335-354, jan./abr. 2019.

MISKOLCI, R.; CAMPANA, M. "Ideologia de gênero": notas para a genealogia de um pânico moral contemporâneo. Revista Sociedade e Estado, Brasília, v. 32, n. 3, p. 725-747, set./dez. 2017.

MONIZ, J. B. O secularismo hodierno à luz dos instrumentos de financiamento das igrejas e confissões religiosas europeias. Revista Brasileira de Ciência Política, Brasília, n. 23, p. 145-180, maio/ago. 2017. 
MONTERO, P.; SILVA, A. L.; SALES, L. Fazer religião em público: encenações religiosas e influência pública. Horizontes antropológicos, Porto Alegre, Ano 24, n. 52, p. 131-164, set./dez. 2018.

NOVAES, R. Juventude, religião e espaço público: exemplos "bons para pensar" tempos e sinais. Religião \& Sociedade, Rio de Janeiro, v. 31, n. 1, p. 184-208, 2012.

OLIVEIRA JÚNIOR, I. B.; MAIO, E. R. "Não vai ser permitido a nenhum órgão do governo fazer propaganda de opções sexuais": o discurso inaugural no "desagendamento" do Kit Gay do MEC. Revista e-Curriculum, São Paulo, v. 15, n. 1, p. 125-152, jan./mar. 2017.

ORO, A. P.; CARVALHO JUNIOR, E. T. Religiões e eleições 2012 em Porto Alegre. Debates do NER, Porto Alegre, Ano 14, n. 23, p. 109-144, jan./jun. 2013.

PEREIRA, R. Francischini faz mais de 420 mil votos e PSL fica com maior bancada. Publicado em: 07 out. 2018. Disponível em: <http://bit.ly/2XotxKc>. Acesso em: 18 dez. 2018.

PRC. Religião na América Latina: mudança generalizada em uma região historicamente católica. Publicado em: 13 nov. 2014. Disponível em: <https://pewrsr.ch/2YdqFeL>. Acesso em: 23 jul. 2019.

PIERUCCI, A. F. O crescimento da liberdade religiosa e o declínio da religião tradicional: a propósito do censo 2010. Anuac: Cagliari, v. 1, n. 2, p. 87-96, nov. 2012.

PINHEIRO, D. V. L.; SILVA, M. B. Punindo a Eva em projetos de lei: a frente parlamentar evangélica em oposição ao aborto. Religare, João Pessoa, v. 15, n. 2, p. 570-584, jul./dez. 2018.

PRANDI, R.; SANTOS, R. W.; BONATO, M. Igrejas evangélicas como maquinas eleitorais no Brasil. Revista USP, São Paulo, n. 120, p. 43-60, jan./mar. 2019.

ROCHA, D. Venha a nós o vosso reino: rupturas e permanências nas relações entre escatologia e política no pentecostalismo brasileiro. 2009. 146 f. Dissertação (Mestrado em Ciência da Religião) - Pontifícia Universidade Católica, Belo Horizonte, Minas Gerais.

SANTOS, L. R. Confiança ou cabresto? Considerações sobre o comportamento eleitoral de um grupo evangélico nas eleições municipais de 2012. Intratextos, Rio de Janeiro, v. 4, n. 1, p. 73-92, 2013.

SANTOS, R. M. Conservadorismo na Câmara dos Deputados: discursos sobre "ideologia de gênero" e Escola sem Partido entre 2014 e 2018. Teoria e cultura, Juiz de Fora, v. 13, n. 2, p. 118-134, dez. 2018.

SEXUGI, F.; MEZZOMO, F. A.; PÁTARO, C. S. O. À imagem e semelhança: simulacro e hagiografia nas propagandas eleitorais de políticos religiosos. Todas as letras, São Paulo, v. 20, n. 1, p. 224-236, jan./abr. 2018.

SOUZA, E. G. S.; ALMEIDA, T. N. V.; OLIVEIRA, S. Q. Marketing político e eleitoral no agreste do RN: uma análise sobre as estratégias de campanha em 2016. Métodos e Pesquisa em Administração, João Pessoa, v. 2, n. 1, p. 64-75, jan./jun. 2017

VIEIRA, T. R. et al. abuso de poder das igrejas e as eleições de 2018. Publicado em: 19 ago. 2018. Disponível em: <http://bit.ly/309V3YT>. Acesso em: 19 fev. 2019. 
TATAGIBA, L. Os protestos e a crise brasileira: um inventário inicial das direitas em movimento (2011-2016). In: ALMEIDA, R.; TONIOL, R. (Orgs.). Conservadorismos, fascismos e fundamentalismos. Campinas, SP: Editora Unicamp, 2018, p. 87-116.

Submetido em: 10-8-2019

Aceito em: 13-4-2020 